\title{
Author/Title Index to volume 7 (1987)
}

(Numbers appearing within parentheses before the page numbers indicate the issue in which an item was published.)

Binkley, R.D. and J.R. Parrott, A reference-librarian model for computer-aided library instruction

(1) $31-38$

Book Review

(1) $39-41$

Carbonell, J.: see M. Mauldin

$(4 / 5) 103-117$

Cawkell, A.E., Editorial

Chignell, M.H.: see P.J. Smith

(4/5) 95-102

Conference Report

(6) 201-209

Cove, J.F. and B.C. Walsh, Browsing as a means of online text retrieval

(6) $183-188$

Demaret, E.: see K. Schlaefer

$(2 / 3) 85-92$

Fournier, M., Information transfer - a look into the future

(1) $3-12$

Fox, E.A., Testing the applicability of intelligent methods for information retrieval (4/5) 119-138

Hepworth, M.E., Information services in the international network market

(6) $167-181$

Hyams, M., How to profit from information technologies

$(4 / 5) 145-152$

Krawczak, D.: see P.J. Smith

$(4 / 5) 95-102$

Krockel, H. and G. Steven, The integration of materials data banks into a European information service network

$(2 / 3) 51-66$

Landau, H.B., A data-base producer's view of online vendor gateways: a threat or an opportunity

$(4 / 5) 163-165$

Marx, B., Production of scientific and technical research databases in France

Matsumura, T., Resource-sharing for education and research

Mauldin, M., J. Carbonell and R. Thomason, Beyond the keyword barrier: knowledge-based information retrieval

Mendelsohn, L.D., Legislation for personal privacy: its impact on transborder data flow

Miles, I., From the service economy to the information society - and back again?

$(2 / 3) 77-84$

$(2 / 3) 67-76$

$(4 / 5) 103-117$

$(2 / 3) 43-49$

(1) $13-29$

Parrott, J.R.: see R.D. Binkley

(1) $31-38$

0167-5265/88/\$3.50 @ 1988, Elsevier Science Publishers B.V. (North-Holland) 
Rosenberg, V., Post-processing and the 'revolution' in information systems: why hasn't it happened?

$(4 / 5) 153-156$

Rowe, R.R., Information policy and the discovery

(6) 189-199

Schlaefer, K. and E. Demaret, On the usefulness of a project information system demonstrated by the example of the Clearing-House for On-Going Research in Cancer Epidemiology

$(2 / 3) 85-92$

Shute, S.J.: see P.J. Smith

$(4 / 5) 95-102$

Smith, P.J., D. Krawczak, S.J. Shute and M.H. Chignell, Bibliographic information retrieval systems: increasing cognitive compatibility

$(4 / 5) 95-102$

Sprehe, J.T., Implementing the Government's new information policy

$(4 / 5) 139-144$

Steven, G.: see H. Krockel

$(2 / 3) 51-66$

Thomason, R.: see M. Mauldin

$(4 / 5) 103-117$

Unruh, E.L., Introduction

$(4 / 5) 93-94$

Walsh, B.C.: see J.F. Cove

(6) $183-188$

Wilson, J., Machine-aided indexing for NASA STI

$(4 / 5)$ 157-161 